\title{
Discursos sobre o islã e os muçulmanos em livros didáticos
}

Luiz Salgado Neto*

Resumo: O presente trabalho tem o objetivo de apresentar alguns elementos recorrentes contidos nas narrativas sobre o islã e os muçulmanos em livros didáticos dedicados ao Ensino Médio. Observando algumas afirmações estereotipadas e preconceituosas em obras didáticas, pretende-se contribuir para uma abordagem pluralista das sociedades muçulmanas e da fé islâmica em escolas brasileiras; uma abordagem que permita um ensino voltado para a apresentação do outro de forma positiva; e para que o diferente seja visto como parte integrante da sociedade, não como alguém exótico e potencialmente adversário. Busca-se observar o islã e os muçulmanos a partir das noções elaboradas pelos estudos interculturais, tendo como objetivo contribuir para uma educação que valorize a coexistência com o diferente. Com isso, busca-se refletir sobre um ensino que construa um mundo mais inclusivo, menos fechado, menos xenófobo e menos violento.

Palavras-chave: Livro didático, Islã, Muçulmanos, Religião, Educação.

Abstract: This paper aims to present some recurrent elements contained in the narratives about Islam and Muslims in textbooks devoted to secondary education. Watching some stereotypical and prejudiced statements in textbooks, it is intended to contribute to a pluralistic approach of Muslim societies and Islamic faith in Brazilian schools; an approach that allows a teaching

* Graduando em História pela Universidade Federal do Rio de Janeiro - UFRJ - $8^{\circ}$ período. E-mail: salgado_neto@yahoo.com.br 
by which there is a presentation of the Other in a positive way; and so that the different is seen as an integral part of society, not as someone exotic and potentially adversary. This paper seeks observe Islam and Muslims from the notions developed by intercultural studies, aiming to contribute to an education that values the coexistence with the different. With this, we try to reflect on a teaching that builds a world more inclusive, less closed, less xenophobic, less violent.

Keywords: Textbook, Islam, Muslims, Religion, Education.

Nos últimos anos temos assistido a uma forma extremamente nociva e preconceituosa de pensar as relações entre as sociedades muçulmanas e o Ocidente. ${ }^{1}$ No pós-Guerra Fria, o discurso sobre o suposto confronto intrínseco nas relações entre as sociedades ocidentais e as sociedades muçulmanas foi visto como "o" conflito fundamental, ideia delineada de forma sistemática por autores como Bernard Lewis e, principalmente, Samuel Huntington, em seu famoso livro $O$ choque de civilizações.

Para Huntignton (1997, p. 265), este conflito é inevitável, "enquanto o Islã continuar sendo o Islã e o Ocidente continuar sendo o Ocidente". Para o autor, os muçulmanos têm problemas em todos os lugares em que convivem com outras sociedades. Segundo ele, "para onde quer que se olhe ao longo do perímetro do Islã, os muçulmanos tiveram problemas para viver em paz com seus vizinhos” (HUNTINGTON, 1997, p. 326). Enxergando o islã como "uma civilização", Huntington ignora completamente a pluralidade das sociedades muçulmanas e, assim, sua obra lançou as bases teóricas para todo um conjunto de generalizações, estereótipos e preconceitos sobre os muçulmanos. Após o 11 de setembro de 2001, tal construção argumentativa se disseminou pelo mundo e tornou-se um senso comum quase indestrutível.

\footnotetext{
Entendo Ocidente neste trabalho como uma construção histórica caracterizada por elementos da tradição europeia dos séculos XVIII e XIX. O termo não se refere a uma área geográfica específica, mas a um conjunto de sociedades que compartilham as noções políticas e culturais difundidas pelos europeus paralelamente à sua expansão econômica e política pelo globo, no século XIX e início do século XX.
} 
O Brasil não ficou isento dos desdobramentos de tal construção discursiva e há uma grande preocupação com o perigo político do "terrorismo islâmico", que teria fincado bases no sul do país, na Tríplice Fronteira. Além disso, há uma forte tendência no Brasil à disseminação de discursos que enfatizam as diferenças religiosas entre os muçulmanos e os cristãos. Constituído por uma expressiva maioria cristã, evangélica ou católica, o país assiste a um discurso que tende a apresentar o islã e os muçulmanos como adversários, negligenciando o contingente populacional muçulmano que vive no Brasil. ${ }^{2}$ Na última edição do ano de 2009 da Revista Eclésia, uma publicação cristã evangélica, a reportagem de capa traz uma afirmação elucidativa: "Islamização do Brasil: com trabalho social e ênfase na periferia, muçulmanos querem conquistar o país do cristianismo".

A reportagem, de Marcos Stefano, intitulada "um plano para islamizar o Brasil”, traz advertências de que os muçulmanos estão empreendendo um trabalho missionário mais eficiente que os cristãos e, dessa forma, estão obtendo sucesso no que afirmam ser a tentativa de "islamizar o Brasil". Os entrevistados afirmam que os evangélicos estão esmorecendo em seu trabalho de conversão e que os muçulmanos estão aproveitando a oportunidade para expandir seu credo em detrimento da fé cristã, principalmente nas periferias das grandes cidades. Portanto, como o islá também efetua um trabalho para converter pessoas, os cristãos evangélicos veem os muçulmanos como concorrentes em sua missão de atrair mais crentes para sua fé.

A análise feita por um entrevistado sobre a situação atual indica a intensidade do estado de conflito missionário que, para os evangélicos, perpassa toda a sociedade, inclusive a escola.

2 Segundo o censo do IBGE, em 2000, o número de muçulmanos no Brasil era de 27.239, de uma população total de cerca de 170 milhões (IBGE, 2000). No entanto, representantes de organizações muçulmanas contestam esses números, alegando que o total de seguidores do islã no Brasil está entre 700 mil e 3 milhões. Os números são controversos, mas há um certo consenso de que o número de muçulmano no país está em ascensão (BRUM, 2009). 
Segundo o missionário David Botelho, citado pelo autor da reportagem:

a obra missionária não deve se limitar a uns poucos indo para o exterior, mas deve ser feita em nossas ruas, nossa vizinhança e em nossos bairros. Ou daqui a pouco, quando nossos filhos forem à escola, serão eles que voltarão com o Corão, entregue pelo amiguinho da mesa ao lado (STEFANO, 2009, p. 48).

Ainda que saibamos que essa publicação é voltada para um público específico - cristão evangélico -, essa postura é um indicativo de uma percepção no Brasil que vê a população muçulmana como adversária. E, de acordo com essa visão, a escola funcionaria como um campo de batalha por "corações e mentes" dos estudantes.

Este trabalho pretende contribuir para uma visão de que a escola, ao invés de espaço de conflito religioso, deve se constituir como um ambiente de coexistência e de percepção positiva do diferente. Não tratar o diferente como alguém exótico, externo à sua sociedade, mas alguém que é parte de sua convivência. E não só em relação aos muçulmanos, mas, em um país marcado pela diversidade, devemos pensar nas mais variadas religiosidades e comportamentos praticados em várias partes do país que são vistas por muitos como destoantes do "normal".

Para efetivar esta tarefa, este trabalho terá como ponto de partida as noções elaboradas pelos estudos interculturais. Segundo Reinaldo Fleuri,

[...] o trabalho intercultural pretende contribuir para superar tanto a atitude de medo quanto a de indiferente tolerância ante o "outro", construindo uma disponibilidade para a leitura positiva da pluralidade social e cultural. Trata-se, na realidade, de um novo ponto de vista baseado no respeito à diferença, que se concretiza no reconhecimento da paridade de direitos (FLEURI, 2003, p. 2).

No entanto, não basta apenas celebrar a diversidade como se fosse algo natural. Não se trata de levar para a sala de aula um ensino que se limite a celebrar a identidade e a diferença, mas que busque problematizá-las (SILVA, 2003, p. 74). Ou seja, debater as maneiras pelas quais, no passado e no presente, foram construídas 
formas de identificação do eu/nós em contraste com o Outro. Deve ser ressaltado que, como construções sociais, a identidade e a diferença são disputadas, estão em meio a conflitos. Assim, o binômio identidade/diferença é perpassado por relações de poder. O polo dominante na relação apresenta-se como normal, mais correto, "O" parâmetro para julgar o Outro. E, consequentemente, este Outro é apresentado como o desviante, numa escala de hierarquização das identidades (SILVA, 2003, p. 83). Com efeito, segundo Edward Said (2007, p. 34), uma das principais maneiras que a Europa encontrou para construir sua identidade foi demarcando sua diferença em relação ao mundo muçulmano. $\mathrm{E}$, posteriormente, com a imagem do "oriental" muçulmano muito bem construída, a Europa se apresentou como superior.

Além disso, devemos ter em mente que, sendo construções sociais, não sendo naturais, as identidades estão em constante mudança, não são homogêneas, fechadas, prontas. Assim, como Stuart Hall delineia, "em vez de falar da identidade como uma coisa acabada, deveríamos falar de identificação, e vê-la como um processo em andamento" [grifo no original] (HALL, 2005, p. 39).

Algo que também deve ser ressaltado é que a diferença não está só em lugares distantes. Devemos olhar à nossa volta para percebermos que a nossa própria sociedade é repleta de diferentes. Pensa-se a sociedade como homogênea, mas ignora-se como o diferente é parte de nós. Em nosso país, ainda que haja uma espécie de exaltação das "várias faces" do Brasil, quando observamos algumas afirmaçôes, vemos que o Brasil "multifacetado" desaparece e surgem graves preconceitos. Os educadores devem ter em mente que vivemos em tempos pós-modernos, em que da mesma forma que os sujeitos não são vistos mais como unívocos, integrais, homogêneos, percebe-se, cada vez mais, que as sociedades são heterogêneas, repletas de conflitos. Como aponta Sandra Corazza, vivemos o tempo do "desafio da Diferença Pura”, a diferença que está no interior das sociedades. Diferentes

[...] que povoam nossas casas e ruas, salas de aula e pátios de recreio, dias e noites. Diferentes, que são os homossexuais, negros, índios, 
pobres, mulheres, loucos, doentes, deficientes, prostitutas, marginais, aidéticos, migrantes, colonos, criminosos, infantis-adultos, todos os Sem... Os quais, por tanto tempo, ficaram borrados e excluídos, calados e subordinados, dominados e pisoteados pela lógica da IdentidadeDiferença. Mas, que, hoje, são puros, isto é, diferentes em si-mesmos, essencialmente-outros, não-idênticos, outros-diversos. E que lutam para que nunca mais sejam vistos como vítimas ou culpados, fontes de todo o mal, desvios a serem tolerados. Para que nunca mais suas diferenças sejam governadas, traduzidas, calibradas, reparadas, integradas ao velho Princípio da Identidade Universal (CORAZZA, 2002, p. 4).

Assim, os educadores devem apreender o diferente "puro" e perceber seu valor, o valor que tem em si mesmo. Com essa percepção, os educadores afastam-se dos mecanismos de julgamento, em que se toma uma identidade como padrão e julga-se o diferente como anormal, classificado de forma inferior em uma hierarquia de valores.

Além disso, deve ser ressaltada a heterogeneidade de formas pelas quais os sujeitos vivem e transitam em sociedade. Assim como há várias formas de identificação, há múltiplas formas de se demarcar socialmente. Vivemos em uma época marcada por uma "explosão de marcadores sociais". Ainda segundo Sandra Corazza:

Marcadores que abrem a agenda educacional para questôes de gênero, escolhas sexuais, nacionalidade, multiculturalismo, religiosidade, papel construcionista da linguagem, força da mídia e dos artefatos culturais, processos de significação e disputas entre discursos, políticas de identidade, novas comunidades, imigrações, xenofobia, integrismo, racismo, etnocentrismo (CORAZZA, 2002, p. 5).

Dessa forma, os educadores devem ter em mente que a sociedade integral sem conflitos deu lugar à sociedade conflituosa, de diferentes faces e diferentes marcadores sociais e identitários.

Logo, trabalhando com a percepção desta complexidade, o professor pode contribuir para uma educação mais democrática, em que haja a plena integração de todos na sociedade, independentemente de suas diferenças. Dessa forma, a escola pode ajudar a construir uma sociedade em que as pessoas não sejam excluídas por serem diferentes, e na qual seja praticada 
uma pedagogia que permita a coexistência respeitosa entre todos. Por isso, não é objetivo deste trabalho pregar a "tolerância”, pois isso pode significar que o estudante deve tolerar o diferente, como alguém indesejado - é tolerado, mas não aceito como ele é. O que se deve apresentar aos estudantes é que este Outro faz parte de sua convivência e que ele deve aprender a coexistir com ele, através de uma relação de respeito e reconhecimento de seus direitos de exercer livremente sua maneira de viver.

Assim, algo importante para auxiliar o professor nesta tarefa é um material didático de qualidade. Evidentemente, o professor não pode utilizar o livro e outros recursos didáticos como "a" verdade, debruçando-se sobre eles como se fossem dogmas. $\mathrm{O}$ professor pode e deve fazer as ressalvas necessárias sobre qualquer conteúdo inapropriado nas obras que utiliza. Contudo, como um recurso utilizado também em casa, essa atuação do professor pode ser prejudicada, pois geralmente os pais veem o livro como um material acima de qualquer suspeita, o depósito da verdade. Dependendo do grau de equívoco contido na obra, o trabalho do docente pode ser prejudicado consideravelmente. De qualquer maneira, é importante poder contar com um material de qualidade em sala de aula. Se o livro será um recurso de apoio, então sua qualidade é fundamental.

Assim, este trabalho estará voltado para fazer algumas críticas quanto ao conteúdo dos livros didáticos destinados ao Ensino Médio com relação aos muçulmanos e ao islã. Não será um estudo exaustivo de diversos livros didáticos, mas uma análise sobre alguns pontos recorrentes e mais graves que alimentam preconceitos e mal-entendidos. Serão analisados três livros didáticos. Em dois deles, serão apresentados os principais problemas na apresentação do tema. A última obra analisada será apresentada por conta de seus aspectos positivos, pois, embora possua alguns problemas, grande parte de seu conteúdo poderá ser tomado como referência de uma apresentação do islã e dos muçulmanos que tenha qualidade e que cumpra os requisitos para uma sociedade que saiba lidar adequadamente com sua pluralidade. 


\section{História: texto e contexto}

A primeira obra analisada neste trabalho é História, texto e contexto, de autoria de Roberto Catelli Junior, lançado pela editora Scipione. O livro traz conteúdos de História Geral e História do Brasil, apresentados em sete "Unidades Temáticas", perfazendo um total de 688 páginas. O interessante da obra é que seu conteúdo é apresentado sob uma perspectiva comparada. Assim, o livro não segue a cronologia tradicional, mas também não é totalmente destituído de cronologia. No interior de cada unidade temática, há uma divisão cronológica - a comparação entre temas das Idades Antiga, Média, Moderna e Contemporânea. A história do islá é incluída na parte temática "Dominação e Conflito Cultural", sendo apresentada no conteúdo referente à Idade Média.

Assim como na maior parte dos livros didáticos observados no Brasil, a Idade Média é apresentada tendo por base a historiografia produzida pela École des Analles, sobressaindo Jacques Le Goff e Marc Bloch. Além destes, muito citado é o historiador brasileiro Hilário Franco Júnior, que, por sua vez, também é influenciado pelos Analles, tendo cursado pós-doutorado na École des Hantes Etudes en Sciences Sociales, em Paris, com o próprio Jacques Le Goff.

Esse não é um aspecto menor da análise de um livro didático. A bibliografia utilizada é um indicador de que linha será seguida na obra. Obter um referencial bibliográfico adequado ao tema apresentado é importantíssimo. Obviamente, o autor do livro didático fará suas escolhas. Utilizar a historiografia dos Analles significa adotar certas posturas. As mais problemáticas, em meu entender, são: 1) a excessiva tendência a buscar "estruturas", sem prestar a devida atenção a aspectos particulares, exceções, singularidades etc., o que pode favorecer generalizaçóes; e 2) um certo francocentrismo, isto é, uma forte tendência a ver o território que se tornará a França como um padrão da Idade Média, utilizando, algumas vezes, determinadas generalizaçóes do que ocorria nessa região para toda a Europa. 
Quanto ao islã, um problema grave contido no livro é a escassa atenção dispensada à religiosidade islâmica e às sociedades muçulmanas. Confirmando o eurocentrismo, ou melhor, o francocentrismo já mencionado, o surgimento e a expansão do islã são apresentados somente em função da Europa. O autor aborda a relação das sociedades muçulmanas com os europeus somente para narrar o processo de expansão europeia que irá culminar no descobrimento da América. Eis como ele inicia sua narrativa:

Para estudarmos o processo histórico que resultou na expansão marítima europeia, precisamos retomar os conflitos com os árabes, principalmente na Península Ibérica, e a história da formação de alguns Estados europeus [grifo no original] (CATELLI JUNIOR, 2006, p. 128).

Além de enfatizar que estudar os muçulmanos só é importante para se compreender a expansão marítima europeia, essa afirmação também contém um equívoco em termos de conteúdo: as populações muçulmanas que residiram na península Ibérica e que construíram entidades políticas como o Califado de Córdoba, eram em sua maior parte oriundas do Norte da África. A maioria dos imigrantes muçulmanos não veio das regiões de maioria árabe do Oriente Médio, mas do Magreb (HOURANI, 2006, p. 70). Portanto, não eram árabes. Assim, as principais batalhas entre cristãos e muçulmanos na península Ibérica opunham, de um lado, aragoneses, leoneses, castelhanos e, em algumas ocasiões, tropas vindas das partes meridionais do Reino Franco; e de outro, almorávidas (de origem berbere, da área onde hoje, em linhas gerais, fica o Marrocos) e almôadas, também norte-africanos (HOURANI, 2006, p. 122; GUICHARD, 2002, p. 637-40). Embora não possamos afirmar com certeza a quantidade de árabes entre este contingente muçulmano, a esmagadora maioria da população que estava sendo combatida pelos europeus era de origem étnica norte-africana e não árabe.

Dessa forma, ao não delimitar bem a origem étnica destes muçulmanos, o livro traz afirmações que podem levar os estudantes a concluir que todo muçulmano é árabe, um equívoco bastante problemático, já que a afirmação de que nem todo 
muçulmano é árabe e nem todo árabe é muçulmano já se tornou quase senso comum. É preciso, portanto, que o livro estabeleça uma diferença entre árabe (origem étnica) e muçulmano (adepto do islã). Portanto, o correto a dizer seria que houve confrontos entre cristãos e muçulmanos na península Ibérica.

Um outro ponto significativo, que já foi muito bem assinalado por Ana Gomes de Souza (2006), é que muitos livros se referem a Allah como o "deus dos muçulmanos", levando o estudante a uma conclusão, equivocada, de que os muçulmanos adoram um deus diferente dos cristãos e judeus. Catelli Júnior (2006, p. 128) diz que "Maomé, nascido em Meca, em 570, era o profeta fundador dessa religião [islã], que acreditava na existência de um só Deus, Alá, e tinha como livro sagrado o Alcorão”. Dessa forma, Allah seria um deus exclusivo da fé muçulmana, totalmente afastado de suas origens judaico-cristãs. Embora saibamos que Allah era uma divindade cultuada pelos árabes antes de Maomé, como "Deus do Alto" (ARMSTRONG, 2008, p. 180; HOURANI, 2006, p. 36), foi a partir de contatos de árabes com judeus e cristãos que a figura de Allah passou de um deus dentre outros para se tornar o único Deus. Além disso, confirmando a confluência do "Deus" das três grandes religiões monoteístas, Allah é como os judeus e cristãos de língua árabe denominam seu deus (HOURANI, 2006, p. 36).

A narrativa sobre o islã no livro continua e continuam também os equívocos. Catelli Júnior diz que

[...] no ano cristão de 622 , foi criado um novo calendário que teria como ponto de partida a fundação da nova religião. Em seguida, os inimigos de Maomé foram expulsos de Meca, lugar de peregrinação dos povos da Arábia e importante centro comercial, e ela tornou-se a cidade sagrada da religião de Alá (CATELLI JUNIOR, 2006, p. 128).

$\mathrm{Na}$ verdade, o ano de 622 foi quando ocorreu a fuga de Maomé de Meca para Yathrib, que se passaria a chamar no futuro Medina - al Madinah al Munawwarah (cidade do profeta). Apenas posteriormente o calendário foi criado aludindo à Hégira (bjira), como ficou conhecido o evento da fuga de Maomé para 
Medina (HOURANI, 2006, p. 84). E em 629, Maomé retornou para Meca, cujos líderes a entregam praticamente sem resistência (HOURANI, 2006, p. 39), tornando-a a cidade religiosa mais importante para os muçulmanos. Portanto, não foi em 622 que o calendário foi criado. Há uma nítida confusão entre os acontecimentos. Esse equívoco na narrativa demonstra um relativo descaso pelo rigor historiográfico, evidenciando a pouca preocupação do autor em sua apresentação do islã e dos muçulmanos.

Por fim, é preciso ressaltar que Catelli Júnior insere a análise do islã na unidade temática "Dominação e Conflito Cultural", o que já sugere um posicionamento do autor. Ele negligencia por completo os contatos culturais e políticos que existiram entre cristãos e muçulmanos. Deveriam ser destacados exemplos de interaçôes culturais e alianças políticas. Sob o aspecto cultural, seria interessante citar o surgimento da arte chamada "moçárabe", que existiu na península Ibérica, por volta dos séculos IX e X, e que se manifestava principalmente na arquitetura, onde podemos ver influências muçulmanas no desenho das igrejas (GUICHARD, 1995, p. 636). Poderiam ser utilizados recursos iconográficos para ilustração, como fotografias de igrejas e mosteiros na Espanha de hoje que foram construídos segundo esse modelo de arquitetura. Sob o ponto de vista político, poderiam ser citadas as relações amistosas - recíprocas - do cristão Baudoin IV, rei de Jerusalém, em relação a Saladino, durante as Cruzadas, por volta do ano 1183 (MAALOUF, 2007, p. 174). Poderia ser utilizado um documento do período que aborda essa relação política: uma narração de viagem de Ibn Jobair, viajante andaluz em Damasco. Ele conta, surpreendido, em 1184, que apesar de cristãos e muçulmanos estarem oficialmente em guerra, o trânsito de caravanas é normal. Segundo ele

os cristãos fazem os muçulmanos pagarem uma taxa que é aplicada sem abusos. Os comerciantes cristãos, por sua vez, pagam direitos sobre suas mercadorias quando atravessam o território dos muçulmanos. O entendimento entre eles é perfeito e a equidade é respeitada. Os guerreiros se ocupam com a guerra, mas o povo permanece em paz (apud MAALOUF, 2007, p. 174). 
Contudo, Catelli Júnior não dedica qualquer parte da obra para abordar esses contatos. $\mathrm{O}$ autor enfatiza somente o aspecto violento. Assim, centrando suas atenções na Europa, o autor passa a narrar as duas frentes de contato entre cristãos e muçulmanos unicamente sob o aspecto da violência, através da narração da "Reconquista" e das Cruzadas.

Catelli Junior dedica mais espaço para a Península Ibérica, pois ele está interessado em entender a expansão marítima europeia, para o que, segundo ele, é preciso observar as lutas cristãs contra os muçulmanos. Após isso, o autor dedica cinco parágrafos para narrar a outra frente de contato, o Oriente Médio, quando escreve sobre as Cruzadas. Baseando-se na definição de Cruzada, de Hilário Franco Júnior, como exposta em seu livro As Cruzadas (FRANCO JR., 1995), Catelli Júnior (2006, p. 129) centra toda a sua análise no lado europeu. Expõe o que ele considera algumas causas da movimentação militar dos cruzados com destino à Palestina - remissão dos pecados, cancelamento de dívidas, saques; apresenta características de algumas expedições; e, inclusive, cita a Bíblia para indicar quais seriam os elementos do imaginário cristão que impulsionaram os cruzados. Não há nada em relação ao lado muçulmano do conflito. E o autor não poderia alegar a ausência de bibliografia, pois há em português a excelente obra de Amin Maalouf, As cruzadas vistas pelos árabes (2007).

Assim, em meu entender, a abordagem do islã neste livro é extremamente problemática. $\mathrm{O}$ autor dedica um espaço muito reduzido ao tema (apenas três páginas); menciona as sociedades muçulmanas apenas em função de seus contatos com a Europa; e comete equívocos em relação aos conteúdos. No entanto, essas escolhas nunca são casuais. A obra apresenta uma posição marcadamente francocêntrica e cronocêntrica. Ou seja, toma como modelos de sociedade e de conduta a França - negligenciando as contribuições de estudar outras áreas do mundo - e a atualidade - falhando em analisar os seres humanos medievais observando-os a partir de seus valores e não dos nossos.

Uma solução, de acordo com a estrutura do livro de Catelli Junior, seria inserir uma unidade temática intitulada "Religião e 
Religiosidade" para dar conta das diferentes manifestações humanas em relação ao sagrado, no passado e no presente. O autor poderia utilizar, para isso, o estudo das "mentalidades", fornecido pelo próprio instrumental teórico da Ecole des Annalles, com o qual ele já trabalha. Seria uma importante contribuição para a derrubada de preconceitos étnicos e religiosos.

\section{Toda a História: História Geral e História do Brasil}

O próximo livro a ser analisado é Toda a História: História Geral e História do Brasil, de José Jobson Arruda e Nelson Piletti, lançado pela Editora Ática em 2004, em sua $12^{\mathrm{a}}$ edição. A obra, segundo os autores, é "simples, sem perder a profundidade", destinado a reunir "em um único volume o essencial de toda a História” (ARRUDA; PILETTI, 2004, p. 3). O livro é dividido em 13 unidades, começando com a história dos primeiros seres humanos, trazendo a pergunta "de onde viemos?" e termina com a pergunta "para onde vamos?", na unidade temática relativa a "Globalização e crise", que analisa o início do século XXI. A obra contém 490 páginas, completadas por questões do Exame Nacional do Ensino Médio (ENEM) e de provas de vestibulares.

Sem dúvida, é um trabalho audacioso escrever sobre toda a história nessa quantidade de páginas e há o risco de perder a "profundidade" aludida no início da obra. Há uma enorme quantidade de informações sobre os vários contextos históricos que serão negligenciados e tomados como se nem mesmo tivessem ocorrido. $\mathrm{E}$, algo importante para o objeto de análise deste trabalho, há o risco de surgirem generalizações.

A abordagem do islã está inserida na unidade temática dedicada à Alta Idade Média. A narrativa é realizada no capítulo 27 (ARRUDA; PILETTI, 2004, p. 113-117), em cinco páginas. A generalização e a simplificação exagerada estão contidas logo no primeiro parágrafo da narrativa. 
No Oriente Médio, em uma península árida banhada pelo Oceano Índico e pelo mar Vermelho, nasceu em 630 o Isláo [sic], como resultado da pregação do profeta Maomé. Em pouco tempo, a nova crença, apoiada no princípio da "guerra santa" - se expandiria por extenso território, conquistando terras na Ásia, na África e na Europa (ARRUDA; PILETTI, 2004, p. 113).

A abordagem do islã como baseada na "guerra santa" é um aspecto dos mais problemáticos na obra. A expressão aparece no capítulo cinco vezes e é o tom que sobressai na narrativa, como algo presente desde o início da história do islã, pois, para os autores, essa é a principal característica da expansão muçulmana, já que "Maomé passou a pregar aguerra santa-jïhah em árabe" (ARRUDA; PILETTI, 2004, p. 114). O aspecto violento da expansão muçulmana e de seu contato com o Ocidente é o que é destacado pelos autores. Embora os autores apresentem os elementos culturais que o Ocidente absorveu da cultura muçulmana, o tom violento sobressai. Na parte 6 do capítulo 27, intitulada "O Ocidente e o Islā", os autores destacam uma inimizade quase intrínseca:

Ao dominar quase toda a região em volta do mar Mediterrâneo, os muçulmanos praticamente cortaram o elo entre a Europa e o Oriente, ligação que passou a ser monopolizada por eles. Com isso, o comércio dos cristãos europeus quase desapareceu na região. A economia baseada na moeda enfraqueceu. Amedrontadas, as populações litorâneas, com algumas exceções, refugiaram-se no interior e passaram a se dedicar à agricultura. A decadência da economia de mercado acentuou a tendência da Europa para a ruralização e, portanto, para a economia feudal (ARRUDA; PILETTI, 2004, p. 116).

Percebemos neste trecho uma tendência na narrativa de negativizar o contato entre o islã e o Ocidente. As expressões usadas demonstram essa percepção: "cortar o elo", "comércio quase desapareceu”, "economia baseada na moeda enfraqueceu”, "populaçôes amedrontadas", "decadência da economia de mercado". Todo o parágrafo indica que o Ocidente teve prejuízo em seu contato com o islã. Os autores, se posicionando na Europa e se fundamentando em uma história que se debruça em grande medida nos aspectos econômicos, veem o avanço do islã como 
um vetor de atraso na economia europeia e no padrão de vida dos cristãos ocidentais.

Ao afirmar que o islã provocou a fuga das populações litorâneas para o interior, os autores negligenciam que este fenômeno já ocorria desde o século II, quando se iniciou um processo de ruralização em todo o Império Romano. Com a desorganização do aparelho estatal romano, a aquisição de alimentos nas cidades havia se tornado precária e surgiu a necessidade de produzir alimentos diretamente no campo. Dessa forma, o esvaziamento das cidades litorâneas deveu-se à ruralização da sociedade, que migrava para o campo em busca de alimentos (FRANCO Jr., 2006, p. 19). Essa interiorização não foi, portanto, um processo desencadeado pelos muçulmanos e nem mesmo intensificado, pois devemos lembrar, muitas populações cristãs permaneceram no interior da península Ibérica após o domínio muçulmano.

O termo jihad é o que mais provoca confusões no estudo sobre o islã. A palavra é traduzida para os idiomas ocidentais como "guerra santa" e como o instrumento utilizado pelos muçulmanos para eliminarem os seguidores de outras religiões e forçarem os povos submetidos a se converterem ao islã. Contudo, as traduções mais corretas da palavra seriam "esforço supremo" ou "combate sagrado no caminho de Deus”. Significa, na verdade, uma luta espiritual entre as obrigaçôes do crente (cumprir os cinco pilares do islã) ${ }^{3}$ e as vicissitudes de sua vida (MASSOULIÉ, 1996, p. 117). Por exemplo: um muçulmano vivendo em um país ocidental poderia se sentir envergonhado, dependendo do lugar em que estiver, em se curvar em direção à Meca e realizar sua oração. Surgiria então um dilema: fazer a oração ou não? Essa seria sua jihad. Somente em último caso a guerra seria um instrumento da jïhad, em defesa e não para o ataque. Segundo Ana Gomes, o próprio Alcorão menciona que o muçulmano não poderia obrigar uma outra pessoa a se converter (Folha de São Paulo, 2006).

3 Os cinco pilares são: entoar a confissão "Só há um Deus e Maomé é seu Profeta"; realizar a oração em direção a Meca cinco vezes ao dia; doar uma certa quantia em dinheiro; jejuar no mês do Ramadã, do nascer ao pôr-do-sol; e realizar o hajj, a peregrinação a Meca, pelo menos uma vez durante a vida. 
Segundo Rudolph Peters (2008, p. 1), o conceito de jihad remonta aos primórdios do islã, aludindo às guerras travadas por Maomé. No entanto, como já mencionado, o termo é muito mais amplo do que "guerra santa". Se pensarmos na palavra com este sentido, devemos inserir a noção de jihad em seu contexto da Arábia do século VII, pois referia-se a um ambiente já de antemão extremamente belicoso, muito antes do advento do islã. As escaramuças entre as tribos árabes eram onipresentes, garantidas pelos costumes locais e somente paralisadas por breves tréguas. As lutas que ocorreram entre Maomé e seus seguidores contra os coraixitas talvez se devesse mais a disputas por rotas de caravanas do que por questôes religiosas (HOURANI, 2006, p. 37). Além disso, embora apareçam menções em alguns versos, a doutrina da jihad foi desenvolvida fora do Alcorão, nos hadith. ${ }^{4}$ Foi, portanto, delineada de forma mais aprofundada após a morte de Maomé, no período das conquistas territoriais fora da península arábica (PETERS, 2008, p. 1).

Provavelmente a noção de jibad como guerra santa emergiu juntamente com o surgimento de uma ação militar mais organizada dos muçulmanos, até então pouco expressiva. Só houve a formação de um exército após a morte de Maomé, quando as alianças construídas pelo Profeta ameaçavam se dissolver. Alguns líderes tribais aliados rejeitaram a preponderância do califa Abu Bakr e outros até mesmo rejeitaram Maomé como Profeta. Para conter a dissolução da aliança, Abu Bakr formou um exército organizado e fez uso das armas para manter o califado muçulmano intacto. As guerras na península criaram então um impulso militar que levou os muçulmanos para muito além de Meca. Liderados pelo segundo califa, Omar ibn Abdel Khattab, entre 634 e 644 os muçulmanos unificaram toda a Arábia e conquistaram as províncias da Síria e do Egito do Império Bizantino e partes do Império dos persas sassânidas (HOURANI, 2006, p. 44).

Assim, se podemos encontrar menções à jïhad como guerra santa no Alcorão, é problemático afirmar que há uma inerente

4 Hadith: tradição oral muçulmana; conjunto de máximas atribuídas a Maomé no período inicial do islã. Foram coligidas por juristas islâmicos nos séculos VIII e IX. Tratavam de assuntos do cotidiano, mas também de metafísica, cosmologia e teologia (ARMSTRONG, 2008, p. 210). 
ligação entre o que segundo a tradição são as revelações do islã a Maomé e a "guerra santa", que se tratava mais de instrumento de avanço político imperial do que de doutrina religiosa. É um tema que deve ser tratado, portanto, com extremo cuidado.

Além disso, se o avanço militar pressupunha conversão forçada, como entenderíamos a existência de não-muçulmanos sendo governados pelos califas? De fato, o tema da conversão ao islã gera inúmeras controvérsias. Alguns alegam que a expansão da fé se deu exclusivamente pela força. Contudo, Maomé nunca obrigou cristãos e judeus a se converterem e após a sua morte hinduístas e budistas gozaram de plena liberdade de crença no Império Muçulmano (ARMSTRONG, 2008, p. 200-201). Ademais, segundo estimativas, durante a dinastia omíada (século VIII), apenas 10\% da população das áreas onde hoje são o Irã, Iraque, Síria, Egito, Tunísia e Espanha havia se convertido ao islã (HOURANI, 2006, p. 75-76). Somente no século X a maioria da população do império era muçulmana. Assim, não houve uma grande corrida à conversão paralelamente a expansão do império, nem tampouco conversão forçada, como a maioria dos livros didáticos e mesmo acadêmicos afirmam.

Na verdade, houve diversos vetores da expansão da fé islâmica. Um deles foi a utilização de impostos diferentes para os não seguidores do islã. Ou seja, quem não havia se convertido ao islã, pagava mais impostos. Além disso, como poder político imperial, havia certa tendência de algumas populações nas áreas anexadas a buscarem se enquadrar no novo sistema. A fé comum, assim, garantia acesso dos novos convertidos ao Estado muçulmano. Portanto, muitos novos muçulmanos se convertiam espontaneamente.

Isso se confirma ao analisarmos a expansão do Império Muçulmano, pois tudo indica que a oposição por parte dos povos dominados não era tão forte que exigisse mão de ferro. Segundo Albert Hourani (2006, p. 45), deve haver uma outra explicação, fora a militar, para a aceitação dos árabes pelos povos conquistados. Para a maioria deles, não importava quem estivesse no governo. Para populações habituadas ao controle exercido por um império 
estrangeiro, não importava saber o nome do governante. Para os moradores da cidade, isso não era problema, contanto que houvesse estabilidade, paz e impostos razoáveis. No campo, os impérios interferiam pouco e os habitantes viviam sob seus próprios chefes e seguindo seus próprios costumes.

O grande problema das abordagens que trazem a jihad para o centro da apresentação é a tendência a enxergar o islã como uma religião violenta. Ainda que tenha havido episódios de violência nos primórdios do islã, não devemos tomar isso como a regra e retirar tais eventos de seu contexto. Como Peter Demant (2004, p. 240241) aponta, episódios de violência na são exclusivos da história do islã. Ataques sangrentos realizados por cristãos e judeus podem ser encontrados em diversas épocas históricas e, mais importante, fundamentados nas Sagradas Escrituras (vide salmos de Davi) ou direcionadas pela mais alta figura da hierarquia religiosa (vide as Cruzadas, ordenadas pelo papa Urbano II). Alguns autores, como Samuel Huntigton e Bernard Lewis, afirmam que os episódios de violência perpetrada por muçulmanos estão na "natureza" da religião. E é esse equívoco que se disseminou.

As críticas a esse modo de pensar podem ser construídas a partir de vários pontos. Em primeiro lugar, não há uma essência islâmica. O islã contém em si, da mesma forma que o cristianismo e o judaísmo, uma imensa pluralidade. Quanto ao uso da força, hoje, a maioria dos muçulmanos condena a violência. Após o 11 de setembro, a Organização da Conferência Islâmica condenou os ataques como sendo "bárbaros e criminosos" (BBC, 2008). Em 2005, Ali Mohamed Abdouni (2005), líder da comunidade muçulmana no Brasil, condenou os atentados de Londres, bem como qualquer ato terrorista, que segundo ele, são contrários ao que diz o Alcorão. Mesmo entre o islamismo - o islã como fundamento para a ação política ${ }^{5}$ - isso não ocorre. Apesar de muitos grupos islamistas hoje utilizarem a violência para alcançarem

Segundo Mohammad Ayoob, islamismo é uma doutrina que enxerga o islã como "ideologia política e não como religião ou teologia", isto é, um entendimento de que o islá deve ser o corpo de doutrinas que deve orientar a política e determinar como a sociedade deve ser organizada (AYOOB, 2008, p. 2). 
seus objetivos, a maioria deles está inserido em processos políticos no interior dos países onde atuam. E alguns grupos que ainda se pautam por atos violentos começam a fazer a transição para a arena política eleitoral, como o Hamas, na Palestina, e o Hizbollah, no Líbano (AYOOB, 2008, p. 17-22).

Tais especificidades não podem ser discutidas em livros com escopo tão abrangente, que se proponham a narrar "toda a história". É por isso que a generalização é algo a ser destacado na apresentação do islã e dos muçulmanos nesse livro didático.

Além disso, outras duas generalizações sobressaem na obra: a situação da mulher e a divisão entre xiitas e sunitas. Em primeiro lugar, vejamos o que os autores têm a dizer sobre os xiitas e sunitas. Analisando o que chamam de "o islamismo hoje", os autores afirmam:

As conquistas territoriais levaram à divisão do islamismo em duas seitas principais: xiitas e sunitas. Os xiitas, mais radicais, repudiam os valores do mundo ocidental moderno. Defendem a preservação, a qualquer custo, dos princípios fundamentais do islamismo. Atualmente, a principal força xiita é o Irã.

A facção dos fundamentalistas islâmicos pertence à corrente xiita. Extremamente radicais e conhecidos por suas ações violentas, eles defendem a criação de um Estado muçulmano segundo os preceitos do Alcorão. Os sunitas, embora preservem regulamentos básicos da religião, são mais moderados em suas manifestações religiosas e políticas. [grifo no original] (ARRUDA; PILETTI, 2004, quadro, p. 117).

É difícil até mesmo começar a refutar tamanhos equívocos. De início, os xiitas são qualificados de "mais radicais". Os autores parecem desconhecer completamente sobre o que estão escrevendo. É um erro grave fazer tais afirmações. De fato, a maioria dos xiitas está localizada no Irã, país visto no Ocidente como o representante do "Eixo do Mal", segundo expressão do expresidente estadunidense George W. Bush. Fortalece essa visão o fato de que após a Revolução Iraniana em 1979, o governo do Aiatolá Khomeini criou uma Constituição em grande parte orientada pela sharia, a lei islâmica, e que buscava se afastar do Ocidente, símbolo da política do governo anterior. O fato do Irã 
ser visto como um Estado que patrocina o terrorismo faz com que sua população seja vista como mais radical. Houve, com efeito, um compreensível apoio popular inicial a um movimento que derrubou a sangrenta ditadura do Xá Mohammad Reza Pahlevi (1941-1979). Contudo, se observarmos mais atentamente essa relação hoje, a situação é bastante diferente. A convivência entre governo e população é altamente problemática, principalmente se considerarmos os recentes confrontos de rua entre manifestantes e a polícia após as eleições presidenciais de 2009. Assim, os autores confundem nitidamente os líderes iranianos com a população iraniana.

Considerar os muçulmanos xiitas como radicais é uma generalização totalmente inadequada. Em reportagem para a revista National Geographic em 2004, a repórter Janine Di Giovanni (2004, p. 44-77) demonstrou a complexidade dos xiitas iraquianos e como eles, em certas ocasiões, estão muito próximos dos "valores ocidentais" que os autores afirmam que os xiitas repudiam. A jornalista verificou que muitos xiitas que conheceu eram seculares, instruídos e de classe média, inclusive uma família com quem manteve intenso convívio e que, segundo ela, "não era mais devota que uma típica família de classe média de Nova York ou Paris” (Di GIOVANNI, 2004, p. 62).

Um outro ponto a ser chamado a atenção é que os fundamentalistas islâmicos a que os autores se referem como sendo saídos do xiismo, são oriundos de qualquer parte do islã. Na verdade, isso se torna mais problemático se lembrarmos que há fundamentalistas nas três religiões monoteístas. Os fundamentalistas islâmicos que os autores querem apresentar no livro, aludindo ao 11 de setembro, são na verdade, seguidores do islã sunita, exatamente o grupo que os autores chamam de mais moderados. Porém, é evidente que não são todos os sunitas que são radicais, seria uma outra generalização absurda. A al-Qaeda constitui uma pequena parcela e seus membros são seguidores do ideário Wahhabista. O Wahhabismo teve origem no século XVIII, fundado por Muhhamad ibn Abdel Wahhab (1703-92), que pregava um retorno às leis primordiais 
do islã e combatia "inovações ilegítimas" (HOURANI, 2006, p. 340). Ou seja, buscava resgatar a pureza do islã e abandonar todos os elementos da modernidade, que significava, naquela época, elementos europeus.

A emergência da al-Qaeda na mídia internacional e a grande atenção dispensada a seus atos e ideias, a despeito de todos os exemplos de convivência entre os muçulmanos e os seguidores de outras religiões, trouxe para a imaginação ocidental uma percepção de que os muçulmanos são, além de violentos, avessos à modernidade. Contudo, devemos lembrar que grande parte da cultura antiga ocidental foi recuperada para a Europa pelos muçulmanos. Além disso, se hoje a modernidade está associada à racionalidade, então o islã não pode ser considerado um vetor de atraso. O próprio Alcorão determina que a razão seja utilizada para entender os sinais e as mensagens de Allah, o que possibilitou o futuro sucesso dos muçulmanos nas ciências naturais, enquanto os cristãos enxergavam as ciências como um perigo para a religião (ARMSTRONG, 2008, p. 190). No século XIX, emergiu um movimento que defendia que os ensinamentos do islã deveriam ser compatibilizados com a razão: o salafismo. Muito influenciados pelas idéias ocidentais do século XIX, buscavam compatibilizar o islã com o positivismo e o racionalismo (AYOOB, 2008, p. 6-7). Assim, nada mais equivocado do que defender que o islã é uma religião voltada para o passado.

Quanto à situação das mulheres, outra generalização absurda se encontra neste livro didático. No quadro da página 116, os autores citam o trabalho de J.M. Roberts, "O livro de ouro da história do mundo", tecendo considerações sobre a péssima situação das mulheres em países muçulmanos. Para Roberts

As mulheres judias e cristãs, ao longo da história, sempre desfrutaram de mais liberdade que as muçulmanas. O símbolo mais óbvio é o véu, ainda hoje usado por muitas mulheres em terras islâmicas, e que provavelmente ainda é imposto, pelo menos informalmente, nas regiões onde os fundamentalistas muçulmanos (facção mais radical) estão no poder (apud ARRUDA; PILETTI, 2004, p. 116). 
Em primeiro lugar, Roberts trabalha de forma anacrônica, ao dizer que as mulheres judias e cristãs "sempre" desfrutaram de mais liberdade que as muçulmanas. Ele desconsidera o péssimo tratamento a que eram submetidas mulheres durante a Idade Média, por suas alegadas ligações com os demônios e por serem as culpadas pelo pecado do mundo, pois, segundo a Bíblia, foi Eva quem deu a maçã proibida para Adão comer, desobedecendo às ordens de Deus. Além disso, o autor toma como geral um aspecto local no tratamento das mulheres muçulmanas. É um grande equívoco pensar que as mulheres que eram obrigadas a vestir a burca no Afeganistão dos Talibãs viviam da mesma forma que uma mulher em países muçulmanos do Sudeste Asiático. Em um documentário brasileiro realizado na Malásia, país de maioria muçulmana, o entrevistador passou dias com uma jovem muçulmana, acompanhando sua rotina e suas atividades. O jornalista ficou surpreendido quando via que mulheres muçulmanas saíam sozinhas às ruas à noite e que se divertiam como em qualquer cidade ocidental. Ao visitar a família da entrevistada, o jornalista conheceu uma outra jovem que, quando perguntada sobre o véu, disse que não usava hijab (um dos tipos de véu utilizado pelas muçulmanas), porque segundo ela trata-se de um comprometimento mais profundo com a religião. Para ela, somente quem se dedicasse completamente à religião deveria usar o véu. Ou seja, há total liberdade nesta sociedade para que as mulheres escolham entre usar ou não o tão polêmico véu. Já a entrevistada que usava o hijab afirmou que após começar a usar o véu se sentiu mais "amadurecida" (PASSAGEM PARA. Episódio 25, 2003). Vemos claramente que, na sociedade muçulmana malaia, o véu significa a entrada na idade adulta.

Mesmo nas sociedades árabes do Oriente Médio a generalização sobre a situação das mulheres deve ser problematizada. $\mathrm{Na}$ reportagem da revista National Geographic já mencionada, se destaca uma foto em que duas jovens amigas, uma sunita e outra xiita, aparecem sem véu no campus da Universidade de al-Nahrayn, em Bagdá, comportando-se como qualquer jovem 
ocidental (DI GIOVANNI, 2004, p. 56). Não argumento com isso que as jovens estejam certas por não usar o véu, pois se comportam como ocidentais. Minha meta é chamar a atenção para armadilha de tecer generalizações sobre as sociedades, negligenciando as decisões das pessoas e os graus de flexibilidade de diversos grupos que, teoricamente, seriam encarregados de zelar pelo cumprimento de certas obrigações. Em suma, ser muçulmana não é sinônimo de utilização do véu.

Dessa forma, percebemos que a expressão da religiosidade muçulmana depende do contexto cultural do país e que mesmo em países árabes encontramos mulheres que não usam o véu. E muitas que usam o fazem por livre e espontânea vontade. Na verdade, é um traço frequente em obras didáticas, bem como na grande mídia ocidental, a crítica ao uso do véu pelas mulheres, como um sinal de opressão, não reconhecendo que trata-se de uma prática cultural.

Se observarmos a bibliografia utilizada por José Jobson Arruda e Nelson Piletti para apresentar o islã e os muçulmanos, podemos entender melhor essa avaliação distorcida. Os livros que utilizam são amplos demais para dar conta de qualquer especificidade. Dois deles são "Para entender as religiões" (ou seja, o islã inserido em uma obra que fala de todas as religiões) e o já citado "O livro de ouro da história do mundo" (o islã diluído na "história do mundo"). Tais obras trazem o islã disperso em outros conteúdos de tal maneira que não há como realizar uma apresentação séria e adequada tendo por base apenas esses livros. Há obras, traduzidas para o português, que sem qualquer dificuldade poderiam auxiliar a construir narrativas mais sólidas sobre o islã e os muçulmanos. O livro de Albert Hourani, Uma história dos povos árabes, apesar de não contar uma história dos muçulmanos, contém uma excelente apresentação do surgimento do islã. A obra está acessível e é amplamente utilizada pela sua qualidade. Há também a obra de Peter Demant, $O$ mundo muçulmano, que apresenta os vários contextos em que o islã é praticado, desde o Norte da África até o Sudeste Asiático.

Certamente, se o autor utilizasse obras específicas, isto é, que se dediquem de forma mais aprofundada ao tema, os equívocos 
mencionados não existiriam. Para evitar tais generalizações, o autor poderia de início ler o excelente livro do antropólogo Clifford Geertz, Observando o islã. Nesta obra, Geertz compara as práticas culturais de dois países muçulmanos, Marrocos e Indonésia - em seu dizer, países em que nove de dez pessoas se dizem muçulmanas. No entanto, apesar de ambos serem países muçulmanos, ele afirma:

[...] dizer que o Marrocos e a Indonésia são sociedades islâmicas [...] aponta tanto para suas diferenças quanto para suas semelhanças. A fé religiosa, mesmo quando derivada de uma fonte comum, é tanto uma forma particularizante quanto generalizante; e, de fato, ela [a fé religiosa] surge de sua capacidade de envolver um conjunto cada vez maior de concepções de vida individuais e mesmo idiossincráticas, e, de alguma, forma, de sua aptidão para sustentar e elaborar todas elas (GEERTZ, 2004, p. 27).

Portanto, mesmo a fé sendo comum, a maneira como ela é praticada, vivenciada e experienciada difere de cultura para cultura. Certas práticas consideradas islâmicas são, na verdade, herdadas do período pré-muçulmano. Em certos contextos, os praticantes assimilam muitos aspectos da cultura não muçulmana local e não há entre os seguidores qualquer noção de erro ou pecado em tais assimilações.

Para isso, é bastante interessante recorrer à avaliação de Karen Louise Jolly ao estudar a cristianização da Bretanha. A autora faz uma distinção entre religião formal e religião popular. A religião popular é aquela compartilhada por um grande número de crentes. Ela é mais inclusiva e abrange tanto a esfera ritualística quanto a esfera do cotidiano. Já o que denominou de religião formal seria a ortodoxia da religião, fundamentada em escritos canônicos, prescritos pela autoridade religiosa. Além disso, seria dotada de uma certa estrutura hierárquica, formada por sacerdotes de diversos níveis em relação ao sagrado. Dessa forma, a religião formal seria restrita os círculos sacerdotais, que, teoricamente, deveriam zelar pela ortodoxia da religião. Já a religião popular seria aquela que é vivenciada pelos seguidores em sua vida cotidiana e que, muitas vezes, entra em contradição com 
a religião formal. Para Jolly (1996, p. 9-11), a religião popular é um instrumento acadêmico de hoje para estudarmos práticas compartilhadas amplas e abrangentes em determinada sociedade. Para a autora, ao estudar o que denominamos religião, devemos atentar para dois tipos de contato com o sagrado.

Dessa forma, essa classificação apresenta um importante auxílio para entender os modos de viver a religião e as diferenças assumidas entre o que é prescrito pelos religiosos e o que as pessoas efetivamente praticam. Vemos tal discrepância em todas as três grandes religiões monoteístas. Como Geertz nos diz:

Na Indonésia, assim como no Marrocos, o choque entre o que o Alcorão revela, ou o que a tradição sunita (isto é, ortodoxa) diz que revela, e o que os homens que se chamam de muçulmanos na realidade acreditam se torna cada vez mais inevitável (GEERTZ, 2004, p. 28).

Para Geertz, as maneiras como as elites religiosas trabalharam para lidar com isso foram totalmente distintas. No Marrocos, os líderes religiosos assumiram um rigor sem concessões, adotando um fundamentalismo agressivo que tentaram impor a toda a população. Essa tática contrasta significativamente com a empreendida na Indonésia, onde o islã foi mais "adaptativo, absorvente, pragmático e gradual” (GEERTZ, 2004, p. 29).

Assim, a partir da diferença entre essas duas sociedades muçulmanas, percebemos o quanto de preconceito e estereótipo está subjacente às narrativas históricas que insistem em apresentar o islã como um fenômeno cultural-religioso-social-político homogêneo. E, lamentavelmente, são obras historiográficas com essa orientação que, muitas vezes, ditam o tom dos livros didáticos.

Contudo, há exceções publicadas no Brasil. Livros que permitem uma melhor compreensão do islã e das sociedades muçulmanas. Um deles será apresentado a seguir. 


\section{História: das cavernas ao Terceiro Milênio}

O próximo livro a ser analisado é História: das cavernas ao Terceiro Milênio, de autoria de Myriam Becho Mota e Patrícia Ramos Braick, lançado pela editora Moderna em 2002. A obra é composta de 59 capítulos, totalizando 592 páginas. Mais uma vez, encontramos uma atitude desafiadora: contar toda a história, das cavernas ao Terceiro Milênio. Como já mencionado, corre-se o risco de emergirem generalizações, dado o grande lapso de tempo narrado. Nesta obra, cada capítulo é iniciado com a apresentação de um tema atual para então ser observado no passado. $\mathrm{O}$ islã e as sociedades muçulmanas são apresentados no capítulo 11 , dentro da unidade II, intitulada "a construção de sentidos". O capítulo contém sete páginas e inicia e termina com textos atuais sobre islã e os muçulmanos.

As autoras contornam o risco de generalizações, o que traria prejuízos para a análise do islã e dos muçulmanos, realizando uma apresentação cuidadosa e adotando uma perspectiva pluralista. A primeira página já mostra claramente que as autoras irão tratar o assunto de forma diferente em comparação com os livros didáticos analisados acima. O texto inicial é do livro de Paulo Daniel Farah, o Islã , lançado pela Publifolha. Neste texto, sobre os efeitos do 11 de setembro, Farah mostra que a maioria dos muçulmanos condenou os ataques (apud MOTA; BRAICK, 2002 , p. 96). Deve-se destacar que utilizar como bibliografia uma obra de Paulo Daniel Farah é um indicativo da relevância que as autoras atribuíram ao tema. Farah é especialista em Literatura árabe e professor da Universidade de São Paulo, além de autor de várias obras que versam sobre as sociedades árabes $\mathrm{e}$ muçulmanas, como $A B C$ do mundo árabe. Em suma, é um autor que tem o islã e os muçulmanos como objetos de pesquisa acadêmica. Tal bibliografia é extremamente valiosa para quem pretende apresentar o islã em um livro didático, já que contém uma abordagem não excessivamente aprofundada (isto é, não traz um conteúdo direcionado a especialistas) mas que, por outro lado, não 
é simplificadora, pois demonstra a complexidade das sociedades muçulmanas e as variadas práticas islâmicas. Nesse sentido, as autoras apresentam uma constatação digna de nota:

Generalizações indevidas caracterizam, na maior parte das vezes, a visão que o Ocidente cristão tem do Oriente muçulmano e vice-versa. Pensadores que jamais conviveram nas sociedades que analisam contribuem para interpretações quase sempre preconceituosas das duas religiões em questão (MOTA; BRAICK, 2002, p. 96).

Assim, as autoras apresentam uma visão adequada sobre a coexistência com o diferente. Além de tudo, percebemos que elas não se referem apenas ao Ocidente, mas também aos muçulmanos que generalizam o que seria este "Ocidente". Porém, como bem salientou Edward Said, o Ocidente fala do Oriente porque detém o poder para tanto. Desde o início dos escritos orientalistas, a Europa de fato estava no Oriente islâmico exercendo poder, muitas vezes de colonizador. Said demonstra que o orientalismo criou, através de relações de poder, a figura do "oriental" (SAID, 2007, p. 32-3).

Além disso, as autoras confirmam no final da primeira parte do capítulo sua postura pluralista:

Existem diversas variações da fé islâmica, mas todas têm o Corão como base comum. Hoje o islá concentra-se nas regióes mais pobres do planeta e sofre efeitos do preconceito ocidental. É daí que o fundamentalismo extrai sua força e ganha adeptos entre os seguidores de uma doutrina que prega a tolerância: a raiz do termo islam é salam, que significa "paz" (MOTA; BRAICK, 2002, p. 97).

Deve ser lembrado que, embora o tema do fundamentalismo esteja imerso em um debate controverso, as autoras enfatizam corretamente que islã não é sinônimo de violência, como outras obras sugerem.

Mota e Braick apresentam também adequadamente a ligação que os muçulmanos acreditam haver entre eles e cristãos e judeus, e não que os muçulmanos creem em um deus diferente. As autoras mencionam que Maomé é "considerado pelos muçulmanos como o último profeta enviado por Deus” (MOTA; BRAICK, 2002, p. 97); que "os ensinamentos do Corão apresentam o islamismo 
como a conclusão e o aperfeiçoamento do judaísmo e do cristianismo"; e que "os muçulmanos consideram Jesus e os antigos profetas hebreus como mensageiros de Deus e valorizam suas mensagens de compaixão e igualdade entre os seres humanos" (MOTA; BRAICK, 2002, p. 98).

Quanto à expansão dos muçulmanos e da fé islâmica, as autoras afirmam:

A princípio os muçulmanos foram tolerantes com os povos dominados, o que favoreceu a consolidação da hegemonia do islá. Os vencidos puderam manter suas propriedades, costumes e práticas religiosas, sendo obrigados, porém, a pagar impostos aos dominadores. Por sua vez, aqueles que se converteram ao islá puderam usufruir de privilégios, tais como o acesso a cargos públicos e a isenção de impostos. A tolerância, no entanto, só existia em relação aos judeus e cristãos, os "Povos do Livro", seguidores das religióes monoteístas das quais os árabes se consideravam herdeiros (MOTA; BRAICK, 2002, p. 99).

No entanto, as autoras deveriam matizar a afirmação de que só os "Povos do Livro" eram tolerados. Em primeiro lugar, as populações politeístas não viam problema em absorver mais um deus a seu panteão. Em segundo lugar, Mota e Braick se esqueceram dos zoroastristas, que foram aceitos e tiveram isenção fiscal, pois eram vistos pelos muçulmanos também com certa positividade por também serem monoteístas.

Um outro ponto a ser discutido que é digno de nota são as interações entre cristãos e muçulmanos na península Ibérica. Após as autoras mencionarem os avanços nas ciências e a grande circulação de "sábios e comerciantes das mais variadas origens" no Califado de Córdoba, afirmam que esta "foi uma experiência única na história da humanidade e que tem muito a ensinar a nossa época, marcada pela 'globalização' e por conflitos étnicos e religiosos" (MOTA; BRAICK, 2002, p. 100). Podemos discordar que se trata de uma experiência "única", mas é certamente rara de coexistência entre as mais diversas etnias e religiões.

Além disso, o contato entre muçulmanos e cristãos na península Ibérica é apresentado nesta obra como positivo. Segundo as autoras: 
As contribuições da civilização árabe ${ }^{6}$ na península Ibérica não se limitaram à esfera arquitetônica. $\mathrm{O}$ respeito às características culturais, religiosas e étnicas das tradições monoteístas de muçulmanos, judeus e cristãos permitiu que esses grupos convivessem em relativa paz. Essa lição de tolerância - apesar de alguns períodos em que estiveram no poder governantes marcados pelo fanatismo religioso - é a maior contribuição da presença muçulmana em terras ibéricas (MOTA; BRAICK, 2002, p. 100).

Quanto aos judeus, as autoras afirmam que estes chegaram antes da era cristã e que "deixaram de sofrer perseguição e foram equiparados aos cristãos” (MOTA; BRAICK, 2002, p. 100). Assim, as autoras corretamente enfatizam que se a vida não era um "paraíso", em que havia paz onipresente, a violência não ditava o tom das relações na península Ibérica. Ao contrário: os incidentes eram raros e o que predominava era uma convivência de relativa paz, maior que em muitas outras áreas da Europa.

Ainda quanto à convivência entre cristãos e muçulmanos na península Ibérica, as autoras apresentam um quadro, na página 101, em que citam o texto de Joseph-Maria Piel, retirado da publicação Estrutura do léxico português, que demonstra o grau de contribuições da língua árabe, falada pelos muçulmanos na península Ibérica, para a língua portuguesa. Entre as muitas citadas no quadro estão palavras como aldeia, almoxarife, alfândega, alvará, algodão, açúcar, arroz, cenoura, laranja, almofada, azeite, álcool, alcatrão, marfim, alvenaria, alicerce, algarismo, álgebra, cifra. Esses exemplos nos mostram que os muçulmanos não estão tão distantes do Ocidente como afirmam alguns. E se somarmos ao vocabulário a passagem do conhecimento grego para os europeus durante a Idade Média, veremos que parte importante da história do conhecimento na Europa está ligada à presença muçulmana da península Ibérica.

E, para terminar, as autoras inserem um texto ao final do capítulo sobre a situação das mulheres no mundo muçulmano. O texto, de Melissa Stoeltje, intitulado por baixo do véu das muçulmanas

6 Como já mencionado, seria mais correto substituir a palavra "árabe” por "muçulmana”, para não gerar confusões entre etnia e religião. 
e publicado no Jornal do Brasil em outubro de 2001, demonstra a pluralidade das sociedades muçulmanas quanto à questão e quebra o estereótipo ocidental de opressão. Stoeltje afirma que ocidentais que observam a situação da mulher em alguns países do Oriente Médio e da Ásia Central e que não são familiarizados com o islã se deixam levar por mitos e generalizações. Isto porque, afirma ela, se observadas de perto, a situação da mulher em alguns países muçulmanos é melhor que em países ocidentais. Citando Elizabeth Fernea, professora aposentada da Universidade do Texas e estudiosa do "feminismo islâmico", ela aponta que o Marrocos possui mais advogadas per capta que os Estados Unidos e que o Egito tem mais engenheiras que a Alemanha (apud MOTA; BRAICK, 2002, p. 102). Esse texto é um instrumento importantíssimo para a apresentação da pluralidade das formas de inserção das mulheres nas sociedades muçulmanas.

No entanto, não obstante as importantes contribuições, a apresentação das autoras contém alguns equívocos. O primeiro deles é quanto à jỉhad. Segundo as autoras, nos dez anos seguintes da estada de Maomé em Medina, ele unificou as tribos árabes e unificou a península. Após isso, as autoras dizem que "aqueles que se mostraram hostis a seus ensinamentos foram eliminados militarmente, ação que os islâmicos chamaram jihad, ou Guerra Santa” (MOTA; BRAICK, 2002, p. 98). Ou seja, as autoras incorrem no mesmo erro que as obras didáticas apresentadas anteriormente. Além de se referirem à jïhad como sinônimo de guerra santa, chamam a atenção para a eliminação daqueles que se recusaram a se converter, negligenciando os diversos processos de conversão sem uso da força - as próprias autoras confirmam isso na página 99, no parágrafo citado acima. ${ }^{7}$

Um outro ponto problemático é a denominação do Império Muçulmano como uma teocracia. As autoras dizem que "as normas do Corão também moldaram a organização do Estado islâmico, uma teocracia na qual governo e religião eram inseparáveis”

Página 15 deste trabalho. 
(MOTA; BRAICK, 2002, p. 98). Entendo que o termo "teocracia” merece consideração. Segundo Silvio Ferrari (1998, p. 1237), a teocracia é um ordenamento político em que o líder político é visto como o representante da divindade na Terra ou então ele é um deus. Também é característica de uma teocracia a esfera política estar subordinada à religião e o laicato aos sacerdotes. Além disso, neste sistema, não é prerrogativa do Estado ter ingerência sobre os negócios religiosos. (FERRARI, 1998, p. 1237-1238) Com efeito, Mohammed Ayoob alerta para o fato de que houve sobreposição entre religião e política nos primórdios do islã. No entanto, isso deve ser visto com cautela. Segundo ele, as esferas religiosa e política começaram a ser demarcadas após a morte de Maomé. O califa (sucessor do Profeta) era um líder político mas não poderia se dizer sagrado, pois para os muçulmanos as revelaçôes só eram direcionadas a Maomé. Assim, ao longo de vários séculos, as autoridades religiosas empreenderam um grande esforço para manter unidas as tribos e o império em torno de uma fé comum, muitas vezes negligenciando atos considerados injustos dos governantes, alegando que, segundo Maomé, a obrigação do califa era proteger os territórios do islã (dar al-islam) e assegurar que os muçulmanos realizariam seus rituais e peregrinaçôes sem obstáculos. Assim, cumpridos esses requisitos, as rebelióes contra a autoridade eram vistas como prejudiciais à manutenção da comunidade muçulmana. Assim, os juristas islâmicos utilizavam os ensinamentos do Alcorão para legitimarem um governo. Para Ayoob, a política direcionava a religião e não o contrário. $\mathrm{O}$ caso, para ele, mais emblemático foi o cisma xiita, quando uma dissensão em torno da sucessão política ocasionou uma separação doutrinária (AYOOB, 2008, p. 11).

Podemos discordar desta avaliação utilitarista da religião, como se esta fosse um instrumento dos políticos para manipularem a população. Contudo, não há como duvidar que a fé muçulmana uniu os árabes em torno de um credo comum e os tornou mais propensos a se verem como uma unidade do que anteriormente, quando sobressaíam as rixas tribais e clânicas. Após 
a expansão para fora da península Arábica, era a fé comum que separava os estabelecidos dos outsiders e ser árabe (ou de uma determinada tribo) já não era critério de diferenciação social e política. Então, de fato, a fé comum auxiliou a manutenção de uma entidade política. Assim, embora religião e política estivessem sobrepostas, não entendo que seria correto denominar como teocracia. Entendendo o termo como Ferrari (2008, p. 1237), vemos que a simples ligação entre religião e política não basta para conceituar um sistema político como uma teocracia.

Apesar de alguns equívocos, a obra de Mota e Braick apresenta muito mais pontos positivos do que negativos. Os problemas que surgem podem facilmente serem contornados pelos professores. A abordagem sobre os contatos entre as sociedades muçulmanas e sociedades ocidentais é o ponto forte deste livro didático, já que as autoras não igualam islã a violência e, assim, não veem o contato entre ambos como intrinsecamente violento. Este conteúdo, com algumas retificaçôes pontuais, contribui positivamente para a coexistência entre diferentes, questão muito cara ao presente estudo.

\section{Considerações finais}

De acordo com a proposta explicitada no início deste trabalho, foram verificados graves problemas em duas obras. Devemos lembrar que o conteúdo de um livro didático não deve ser enxergado da mesma forma que olhamos para um livro voltado para o público acadêmico. Daí que alguns equívocos não inviabilizam a utilização de uma obra, pois o professor pode tranquilamente contorná-los, através de uma explicação um pouco mais aprofundada em sala de aula - mas sem a necessidade de conteúdos muito específicos.

No entanto, o conteúdo dos dois primeiros livros analisados contém sérios problemas, pois as obras apresentam um islã distante, exótico e violento. Por ter uma população majoritariamente cristã, seria de imensa importância aproximar os estudantes de sociedades 
que seguem outras religióes para que vejam os diferentes de nossa própria sociedade de forma positiva. $\mathrm{O}$ historiador pode perfeitamente contribuir para tal empreitada, pois o estudo do passado pode auxiliar de forma significativa o caminho para a reflexão e para a derrubada de preconceitos muito atuais. Não só em relação ao islã, mas também às religiôes de origem africana, que ainda sofrem graves preconceitos. Assim, a superficialidade com que o islã e as sociedades muçulmanas são apresentados nestas duas obras prejudica uma abordagem que valorize a coexistência e o respeito às diferenças.

O último livro analisado apresenta uma forma bastante condizente com uma apresentação adequada do tema. Ao enfatizar que há uma grande dose de preconceito (mútuo) na relação entre o que é genericamente chamado de "Ocidente" e as sociedades muçulmanas, as autoras contribuem decisivamente para a reflexão sobre como lidamos com o diferente. Além disso, em suas considerações, derrubam os mais graves equívocos sobre a situação das mulheres. No entanto, quanto à jühad, deixam de apontar os mal-entendidos sobre o termo. Isso, no entanto, pode ser contornado pelo professor, pois o livro sempre se mantém ligado à ideia de que o contato em si não é prejudicial. Se houve conflitos, eles não são naturais. Ao mostrar os contatos entre muçulmanos, cristãos e judeus na península Ibérica, as autoras demonstram que as interações entre diferentes etnias e religiões não implica necessariamente em violência. $\mathrm{E}$, assim, entendo que a apresentação do islã e dos muçulmanos nesta obra condiz com uma abordagem pluralista.

Seguindo esta perspectiva, o autor de um livro didático pode fazer da História um instrumento importantíssimo, pois pode mostrar para os estudantes que as diferenças entre culturas são construídas ao longo da história e que não há antítese natural entre culturas diferentes - como a fórmula atualmente mais disseminada expressa no antagonismo entre "Ocidente" e "Islâ". Para isso, uma abordagem mais detida do islã e dos muçulmanos nos livros é de extrema importância. Hoje, vivemos em um mundo 
em que os seguidores do islã são frequentemente definidos como radicais e fanáticos, como se formassem um todo homogêneo, principalmente após os atentados de 11 de setembro de 2001. Com isso, tendeu-se a se acentuar o preconceito contra os muçulmanos, generalizando uma orientação religiosa minoritária. Por isso, é fundamental que os profissionais da educação trabalhem para, de uma forma pedagógica eficiente, derrubar tais preconceitos. Sem se aprofundar no tema mais do que o necessário, o livro didático deve estar atento à produção acadêmica dedicada ao tema e levá-la aos estudantes como forma pedagógica de clarificar culturas em seu contexto e como forma de respeito às diferenças. Ainda que saibamos que o livro didático não é um escrito sagrado e que o professor pode e deve fazer as correções necessárias em sala de aula, é um instrumento importantíssimo a ser utilizado, que não pode ser negligenciado.

Por fim, entendo que um livro didático de qualidade deveria ressaltar que o muçulmano, o judeu, o africano, o cigano, o eslavo, o russo etc. não são adversários a priori dessa entidade genericamente chamada de "Ocidente". Deve demonstrar, ademais, que as sociedades são complexas, heterogêneas e nem sempre se colocam em conflitos com outras. Se houve e se há conflitos culturais, devemos observá-los historicamente, inserindo-os em contextos nos quais estão envolvidos diversos outros fatores, como interesses políticos, econômicos, estratégicos etc. Só assim, apreendendo a pluralidade humana e sua atuação na história, podemos compreender os outros, assim como a nós mesmos.

\section{Referências}

\section{Livros didáticos}

ARRUDA, José Jobson; PILETTI, Nelson. Toda a História: História Geral e História do Brasil. São Paulo: Editora Ática, 2004.

CATELLI Jr., Roberto. História, texto e contexto. Ensino Médio, volume único. São Paulo: Scipione, 2006. 
MOTA, Myriam B.; BRAICK, Patrícia R. História: das cavernas ao Terceiro Milênio. São Paulo: Moderna, 2002.

\section{Bibliografia}

ABDOUNI, Ali Mohamed. O islã prega a paz. Depoimento de Ali Mohamed Abdouni à Revista Veja. Entrevistador: José Eduardo Barella. Edição 1914, 20 de julho de 2005. Disponível em http://veja.abril.com. br/200705/entrevista.html. Acesso em 4 mar. 2010.

ARMSTRONG, Karen. Uma história de Deus: quatro milênios de busca do judaísmo, cristianismo e islamismo. São Paulo: Companhia das Letras, 2008.

AYOOB, Mohammed. The many faces of political Islam: religion and politics in the Muslim world. Michigan: University of Michigan Press, 2008.

BRUM, Eliane. Islã cresce na periferia das cidades do Brasil. In: Época. Versão online. 30 jan. 2009. Disponível em http://revistaepoca.globo. com/Revista/Epoca/0,_EMI25342-15228,00-ISLA+CRESCE+NA + PERIFERIA+DAS+CIDADES+DO+BRASIL.html. Acesso em 24 jul. 2010.

CORAZZA, Sandra M. Educação do diferente. Palestra no $7^{\circ}$ Colóquio CLACSO - ANPEd: "A colonialidade do saber e o sentido da escola na América Latina", na mesa, a escola e as políticas da diferença: perspectivas pós-coloniais. 01 de outubro de 2002, Caxambu, Minas Gerais. Disponível em www.anped.org.br/reunioes/25/textoclaccsosandracorazza.doc Acesso em 2 mar. 2010.

DEMANT, Peter. O mundo muçulmano. São Paulo: Contexto, 2004.

DI GIOVANNI, Janine. Perto do poder: a chance dos xiitas. In: National Geographic Brasil, São Paulo, ano 5, n. 50, p. 44-77, jun. 2004.

FERRARI, Silvio. Teocracia. In: BOBBIO, Norberto et. al. Dicionário de Política. 11 ed. Brasília: Editora UNB, p. 1237-1238, 1998.

FLEURI, Reinaldo M. Intercultura e educação. In: Revista Brasileira de Educação, n. 23, p. 23-35, maio-ago. 2003. Disponível em www.scielo. br/pdf/rbedu/n23/n23a02.pdf. Acesso em 2 mar. 2010.

FRANCO Jr., Hilário. A Idade Média: nascimento do Ocidente. São Paulo: Brasiliense, 2006. 
. As Cruzadas: Guerra Santa entre o Ocidente e o Oriente. São Paulo: Moderna, 1995.

GEERTZ, Clifford. Observando o islã: o desenvolvimento religioso no Marrocos e na Indonésia. Rio de Janeiro: Jorge Zahar Editora, 2004.

GUICHARD, Pierre. Islã. In: LE GOFF, Jacques; SCHMITT, JeanClaude (Orgs.). Dicionário temático do Ocidente Medieval v. 1. São Paulo: Imprensa Oficial de São Paulo; Bauru: EDUSC, p. 633-649, 2002.

HALL, Stuart. A identidade cultural na pós-modernidade. 10 ed. Rio de Janeiro: DP\&A, 2005.

HOURANI, Albert. Uma história dos povos árabes. São Paulo: Companhia das Letras, 2006.

HUNTIGNTON, Samuel. O choque de civilizações: e a recomposição da ordem mundial. Rio de Janeiro: Objetiva, 1997.

IBGE (Brasil), Censo Demográfico 2000. Tabela 1.1.2: População residente, por situação de domicílio e sexo, segundo a religião - Brasil. Disponível em http://www.ibge.gov.br/home/estatistica/populacao/ censo2000/primeiros_resultados_amostra/brasil/pdf/tabela_1_1_2.pdf. Acesso em 24 jul. 2010.

JOLLY, Karen. Popular religion in late Saxon England: elf charms in context. North Carolina: North Carolina Press, 1996.

LIVROS didáticos distorcem o islamismo. In: Folha de São Paulo, 29 de março de 2006. Disponível em http://aprendiz.uol.com.br/content/ clofrodive.mmp. Acesso em 24 fev. 2010.

MAALOUF, Amin. As cruzadas vistas pelos árabes. São Paulo: Brasiliense, 2007.

MASSOULIÉ, François. Os conflitos do Oriente Médio. São Paulo: Editora Ática, 1996.

PASSAGEM PARA... Episódio 25: Malásia, Jovem, mulher e muçulmana. Apresentação e Direção: Luís Nachbin. Produção Executiva: Alexandre Rocha. Produção e Pesquisa: Rachel Rezende. Roteiro: Luís Nachbin e Arbel Griner. Edição: Marco André Lima e Marcelo Pedrazzi. Canal Futura, Rio de Janeiro, 2003. Futuratec DVD (30 min.), widescreen, cor. 
PETERS, Rudolph. Jihad in classical and modern Islam: a reader. 2. ed. Princeton: Markus Wiener Publishers, 2008.

SAID, Edward. Orientalismo: o Oriente como invenção do Ocidente: São Paulo: Companhia das Letras, 2007.

SILVA, Tomaz T. (Org.). Identidade e diferença: a perspectiva dos estudos culturais. Ed. Petrópolis: Vozes, 2003.

SOUZA, Ana G. Erros históricos permitem formação de conceitos errados sobre Islã e muçulmanos. Entrevista concedida ao Instituto da Cultura Árabe. São Paulo 10 jun. 2006. Disponível em http://www.icarabe. org/CN02/entrevistas/entr_det.asp?id=31. Acesso em 2 jun. 2009.

STEFANO, Marcos. Um plano para islamizar o Brasil. In: Eclésia: a revista evangélica do Brasil, ano 13, 139 ed., p. 40-48, 2009.

TIMELINE: Organization of the Islamic Conference. BBC News. Londres, 18 set. 2008. Disponível em http://news.bbc.co.uk/2/hi/ middle_east/country_profiles/1564339.stm. Acesso em 18 mar. 2010. 
